\title{
Portuguese Version of Simple Go/No-Go Task: Influence of Age in Attention and Response Inhibition Reaction Time
}

\author{
Marco Moniz ${ }^{1,2,3,4^{*}}$, Saul Neves de Jesus ${ }^{3,4}$, Eduardo Gonçalves ${ }^{1}$, João Viseu ${ }^{3,4}$, \\ Andreia Pacheco ${ }^{1,5}$, Susana Moreira ${ }^{1}$ \\ ${ }^{1}$ Department of Psychiatry and Mental Health, Hospital Center of Algarve, Faro, Portugal \\ ${ }^{2}$ António Silva Leal Foundation, Lisboa, Portugal \\ ${ }^{3}$ Faculty of Human and Social Sciences, University of Algarve, Faro, Portugal \\ ${ }^{4}$ Research Centre for Spatial and Organization Dynamics (CIEO), Faro, Portugal \\ ${ }^{5}$ Centre for Biomedical Research (CBMR), Faro, Portugal \\ Email: *emmoniz@gmail.com
}

Received 30 October 2015; accepted 23 February 2016; published 26 February 2016

Copyright (C) 2016 by authors and Scientific Research Publishing Inc.

This work is licensed under the Creative Commons Attribution International License (CC BY).

http://creativecommons.org/licenses/by/4.0/

c) (7) Open Access

\begin{abstract}
Executive functions (EFs) are essential in human functioning, and are an important field of study in neuropsychology. One of the most common disorders concerning EFs is the alteration in response inhibition, fundamental to an adequate behavior. This study aimed to show the initial normative data of 35 healthy subjects ( 22 women and 13 men, with a mean age of 42.60 years old $[S D=14.36]$ ) in a free version of the Go/No-go task. We were able to identify a clear influence of the variable age in reaction time concerning response inhibition and attention.
\end{abstract}

\section{Keywords}

Go/No-Go Task, Normative Data, Response Inhibition

\section{Introduction}

Executive functions (EFs) refer to cognitive competences that allow the subject to determine objectives, find new ways of reaching them, trying to adapt him/herself to various circumstances along that path. An useful way of assessing executive functioning, as well as the severity of executive dysfunctions, being response inhibition one of the most common, involves the utilization of neuropsychological measures (Burgess \& Alderman, 2003).

\footnotetext{
"Corresponding author.
}

How to cite this paper: Moniz, M., de Jesus, S. N., Gonçalves, E., Viseu, J., Pacheco, A., \& Moreira, S. (2016). Portuguese Version of Simple Go/No-Go Task: Influence of Age in Attention and Response Inhibition Reaction Time. Psychology, 7, 254-257. http://dx.doi.org/10.4236/psych.2016.72027 
The Go/No-go task is one of the most applied measures to assess response inhibition. Between the two paradigms of Go/No-go tasks, "simple" and "complex", we find the first to be preferable. On one hand, it does not require an increased working memory, as "complex" Go/No-go tasks do, not relevant for the purpose of our study. Also, it features, the use of pre Supplementary Motor Area (pre-SMA), essential to the selection of an adequate behavior, needed to select an appropriate response or to inhibit an inappropriate one (Simmonds, Pekar, \& Mostofsky, 2008).

Given the importance of this mechanism for clinical practice and the current lack of instruments for its assessment, this study aimed to present the first results regarding normative data of a simple Go/No-go task from the Psychology Experiment Building Language (PEBL) (Mueller, 2013), a free access battery.

\section{Method}

\subsection{Participants}

Our sample comprised 35 healthy subjects, 22 women and 13 men, with a mean age of 42.60 years old (SD = 14.36), a mean of $9.74(S D=3.76)$ years of education and an age range of 17 - 67 years old, recruited from advertisements. All participants were Caucasians and Portuguese speakers.

\subsection{Materials}

A computerized Go/No-go Task (Mueller, 2013), a free software from PEBL Test Battery (Mueller \& Piper, 2014), was performed by every subject, using the same portable computer running the Microsoft Windows 8.1 and an external keypad connected to it.

\subsection{Procedures}

Each participant completed a health and demographic questionnaire which included the MINI (Mini International Neuropsychiatric Interview) (Sheehan et al., 1997) and the BSI (Brief Symptom Inventory) (Canavarro, 2007). Exclusion criteria were current or prior history of mental health disorders, dementia, substance abuse and neurologic disease, including head injury involving a loss of consciousness. To discard simulation, Rey 15-Item Memory Test (15-IMT) was used (Simões, Sousa, \& Duarte, 2010).

This study was approved by the Hospital Center of Algarve Ethics Committee, in conformity with the Helsinki declaration. After having been provided with all the information about the study, all participants signed an informed consent statement.

All analyzes were conducted using the Statistical Package for the Social Sciences (SPSS), version 20.0. The level of significance was set at $p<0.05$.

\section{Results}

We found differences between age groups in accuracy (number of correct responses and number of errors) and in reaction time, with significant effects of age in these results (Table 1 ).

A one-way analysis of variance (ANOVA) showed significant group differences concerning effects of aging, with older patients performing overall more poorly regarding reaction time (P-Go: $F(2,19.8)=9.71, p=0.001$; R-No-go: $F(2,32)=5.57, p=0.008$; R-Go: $F(2,20.5)=7.93, p=0.003)$, accuracy $\left(\mathrm{N}^{\circ}\right.$ corrects: $F(2,19.9)=$ 3.98, $p=0.035$; \% corrects: $F(2,19.7)=3.90, p=0.037)$ and total of errors $\left(\mathrm{N}^{\circ}\right.$ errors: $F(2,19.9)=3.98, p=$ 0.035; \% errors: $F(2,19.7)=3.90, p=0.037)$.

A shared variance of $28 \%$ and $42 \%$ was found in reaction time regarding response inhibition (R-No-go, commission errors: $\left.R^{2}=0.289, F(1,33)=13.34, p=0.001\right)$ and attention (R-Go, omission errors: $R^{2}=0.422, F(1$, 33) $=24.09, p=0.001$ ), respectively (Table 2 ).

\section{Discussion/Conclusion}

According to previous reports (Votruba \& Langenecker, 2013), the influence of aging effects in reaction time was evident, corroborating the importance of motor skills to task performance.

As Go/No-go task representsa crucial instrument to assess response inhibition, the main contribution of this study was the presentation of initial normative data (Table 3), with the purpose of helping clinicians with future 
Table 1. Descriptive statistics $(N=35)$.

\begin{tabular}{|c|c|c|c|c|c|c|c|c|c|}
\hline & \multicolumn{9}{|c|}{ Age Group } \\
\hline & \multicolumn{2}{|c|}{ Total Score $^{\mathrm{a}}$} & \multicolumn{2}{|c|}{$17-39^{b}$} & \multicolumn{2}{|c|}{$40-49^{c}$} & \multicolumn{2}{|c|}{ Over $50^{d}$} & \multirow[b]{2}{*}{$p$-value } \\
\hline & $M$ & $S D$ & $M$ & $S D$ & $M$ & $S D$ & $M$ & $S D$ & \\
\hline \multicolumn{10}{|l|}{ Errors } \\
\hline P-Go & 3.42 & 7.48 & 0.57 & 1.01 & 3.09 & 8.12 & 7.80 & 10.13 & $0.105^{*}$ \\
\hline R-No-Go (Commission Errors) & 5.48 & 3.33 & 4.42 & 2.20 & 5.18 & 2.60 & 7.30 & 4.69 & 0.106 \\
\hline R-Go (Omission Errors) & 0.40 & 0.77 & 0.28 & 0.61 & 0.36 & 0.67 & 0.60 & 1.07 & 0.622 \\
\hline P-No-Go & 1.88 & 2.28 & 1.64 & 1.98 & 1.54 & 1.50 & 2.60 & 3.27 & 0.516 \\
\hline \multicolumn{10}{|l|}{ Percent } \\
\hline P-Go & 97.32 & 5.84 & 99.55 & 0.79 & 97.58 & 6.35 & 93.95 & 7.91 & $0.105^{*}$ \\
\hline R-No-Go (Commission Errors) & 82.85 & 10.42 & 86.16 & 6.90 & 83.80 & 8.12 & 77.18 & 14.66 & 0.106 \\
\hline R-Go (Omission Errors) & 98.75 & 2.42 & 99.10 & 1.91 & 98.86 & 2.10 & 98.12 & 3.35 & 0.622 \\
\hline P-No-go & 98.52 & 1.78 & 98.71 & 1.55 & 98.79 & 1.17 & 97.96 & 2.55 & 0.516 \\
\hline \multicolumn{10}{|l|}{ Reaction Times (ms) } \\
\hline P-Go & 525.65 & 99.29 & 455.10 & 31.46 & 543.15 & 110.99 & 605.16 & 83.58 & $0.001^{*}$ \\
\hline R-No-Go (Commission Errors) & 448.17 & 82.28 & 405.95 & 41.03 & 448.51 & 86.87 & 506.90 & 90.29 & 0.017 \\
\hline R-Go (Omission Errors) & 547.15 & 75.45 & 501.22 & 32.76 & 547.75 & 68.70 & 610.79 & 83.24 & $0.003^{*}$ \\
\hline P-No-go & 486.33 & 68.14 & 489.16 & 57.36 & 439.11 & 37.76 & 529.77 & 81.59 & 0.061 \\
\hline Total Accuracy $\left(\mathrm{n}^{\circ}\right)$ & 308.8 & 10.07 & 313.07 & 4.19 & 309.81 & 10.36 & 301.70 & 12.38 & $0.035^{*}$ \\
\hline$\%$ Accuracy & 96.48 & 3.13 & 97.78 & 1.24 & 96.81 & 3.23 & 94.28 & 3.86 & $0.037^{*}$ \\
\hline Errors $\left(\mathrm{n}^{\circ}\right)$ & 11.20 & 10.07 & 6.92 & 4.19 & 10.18 & 10.36 & 18.30 & 12.38 & $0.035^{*}$ \\
\hline \% Errors & 3.51 & 3.13 & 2.21 & 1.24 & 3.18 & 3.23 & 5.71 & 3.86 & $0.037^{*}$ \\
\hline
\end{tabular}

Note: ${ }^{\mathrm{a}} n=35,{ }^{\mathrm{b}} n=14,{ }^{\mathrm{c}} n=11,{ }^{\mathrm{d}} n=10,{ }^{*}$ Brown-Forsythe.

Table 2. Percentage of variance accounted for by age.

\begin{tabular}{cc}
\hline & Healthy ${ }^{\mathrm{a}}$ \% of Variance) \\
\hline Response Inhibition (R-No-Go) & $M$ \\
Errors & 8 \\
RT (ms) & $28^{1}$ \\
Attention (R-Go) & 3 \\
Errors & $32^{1}$ \\
RT (ms) & \\
\hline
\end{tabular}

Note: ${ }^{\mathrm{a}} n=35,{ }^{1} p \leq 0.001$.

applications of this test. Its main limitation concerns the sample size, which was not wide enough to validate normative data more clearly. Future research should compare larger numbers of subjects and samples should comprise more homogeneous groups, particularly regarding age. 
Table 3. Percentile of healthy subjects.

\begin{tabular}{cccccc}
\hline & \multicolumn{5}{c}{ Healthy $^{\text {a }}$} \\
\hline & 15 & 25 & 50 & 75 & 90 \\
\hline Response Inhibition (R-No-go) & & & & & \\
Errors & 10.00 & 7.00 & 5.00 & 3.00 & 2.00 \\
Percent & 68.75 & 78.13 & 84.37 & 90.62 & 93.75 \\
RT (ms) & 601.58 & 464.75 & 419.20 & 389.62 & 369.66 \\
Attention (R-Go) & & & & & 0 \\
Errors & 2 & 1 & 0 & 0 & 100.00 \\
Percent & 93.75 & 96.87 & 100.00 & 100.00 & 474.02 \\
RT (ms) & 663.14 & 572.80 & 522.59 & 495.87 & \\
Total & & & & & \\
\% Accuracy & 90.81 & 95.93 & 97.81 & 98.75 & 99.02 \\
\% Errors & 9.18 & 4.06 & 2.18 & 1.25 & 0.97 \\
\hline
\end{tabular}

Note: ${ }^{\mathrm{a}} n=35$.

\section{Acknowledgements}

We thank all participants of this study.

\section{References}

Burgess, P. W., \& Alderman, N. (2003). Executive Dysfunction. In L. H. Goldstein, \& J. E. McNeil (Eds.), Clinical Neuropsychology: A Practical Guide to Assessment and Management for Clinicians (pp. 185-209). Chichester: John Wiley \& Sons, Ltd. http://dx.doi.org/10.1002/0470013338.ch9

Canavarro, M. C. (2007). Inventário de Sintomas Psicopatológicos (BSI): Uma revisão crítica dos estudos realizados em Portugal. In M. R. Simões, C. Machado, M. M. Gonçalves, \& L. S. Almeida (Eds.), Avaliação Psicológica: Instrumentos Validados para a População Portuguesa (Vol. III, pp. 305-330). Coimbra: Quarteto Editora.

Mueller, S. T. (2013). The Psychology Experiment Building Language (Version 0.13) [Software]. http://pebl.sourceforge.net

Mueller, S. T., \& Piper, B. J. (2014). The Psychology Experiment Building Language (PEBL) and PEBL Test Battery. Journal of Neuroscience Methods, 222, 250-259. http://dx.doi.org/10.1016/j.jneumeth.2013.10.024

Sheehan, D., Lecrubier, Y., Harnett Sheehan, K., Janavs, J., Weiller, E., Keskiner, A. et al. (1997). The Validity of the Mini International Neuropsychiatric Interview (MINI) According to the SCID-P and Its Reliability. European Psychiatry, 12, 232-241. http://dx.doi.org/10.1016/S0924-9338(97)83297-X

Simmonds, D. J., Pekar, J. J., \& Mostofsky, S. H. (2008). Meta-Analysis of Go/No-Go Tasks Demonstrating That fMRI Activation Associated with Response Inhibition Is Task-Dependent. Neuropsychologia, 46, 224-32. http://dx.doi.org/10.1016/j.neuropsychologia.2007.07.015

Simões, M., Sousa, L., Duarte, P., Firmino, H., Pinho, M. S., Gaspar, N. et al. (2010). Avaliação da simulação ou esforço insuficiente com o Rey 15-Item Memory Test (15-IMT): Estudos de validação em grupos de adultos idosos. Análise Psicológica, 28, 209-226. http://dx.doi.org/10.14417/ap.269

Votruba, K. L., \& Langenecker, S. A. (2013). Factor Structure, Construct Validity, and Age- and Education-Based Normative Data for the Parametric Go/No-Go Test. Journal of Clinical and Experimental Neuropsychology, 35, 132-146. http://dx.doi.org/10.1080/13803395.2012.758239 